\title{
Imagens e figuras de um rei sonhador: representações do milagre de Ourique e do juramento de Afonso Henriques no século XVII*
}

\author{
Luís Filipe Silvério Lima**
}

\begin{abstract}
Resumo:
O artigo analisa a iconografia do Milagre de Ourique, a partir do Juramento de Afonso Henriques, observando a questão da representação dos sonhos em imagens no século XVII. Busca traçar as tópicas e exemplos principais que fundamentaram a iconografia do Milagre bem como da representação dos sonhos em Portugal.
\end{abstract}

Palavras-chave: Ourique, Sonho, Imagem

Pretendo neste artigo apontar alguns aspectos da representação pictórica dos sonhos proféticos no século XVII, tendo como objeto o Milagre de Ourique e a construção da sua iconografia em torno do Juramento de Afonso Henriques. A proposta é traçar os lugares, figuras e repertórios de exemplos que constituíram a versão visual da narrativa do momento da fundação mítica de Portugal, composto por uma gama de augúrios, anúncios, sonhos e profecias. Interessa, nesse processo, perceber como as representações visuais do Milagre dialogaram com uma "gramática" das imagens de sonhos, ligada ao entendimento do que eram visão e profecia e à contraposição entre sono e vigília. Ao mesmo tempo, importa cotejar alguns exemplos que fundamentaram a narrativa, nomeadamente a visão de Constatino, e como isso se refletiu na concepção visual do Milagre. No tecer desses exemplos, tópicas, figuras, iconografias, busco apontar a íntima relação (mas não subordinação) entre as narrativas visuais e escritas, tendo em vista tanto a máxima do ut pictura poesis como regulador da retórica e da poética $^{2}$ quanto a hipótese de se entender a cultura ibérica seiscentista como uma cultura visual, oral e escrita. ${ }^{3}$ Dimensões que eram permeadas por um sentido teológico, pois a própria profecia era tida como uma espécie de visão e, no mesmo passo, anúncio e revelação da Palavra, e a história e vida humana seriam reguladas pela profecia e pelo tempo escatológico e teologicamente instruído, manifestações do Verbo de modo figural ${ }^{4}$.

Na virada do século XVI para o XVII, constituiu-se a forma final da narrativa do Milagre de Ourique, considerado o marco de fundação do reino desde o século XV. A 
partir do Juramento de Afonso Henriques, prova documental forjada para legitimar o Milagre, estabeleceu-se uma narrativa especular de augúrios, visões, previsões, que anunciavam ao mesmo tempo em que confirmavam a aparição de Cristo no céu do Campo de Ourique e a eleição do povo português. Nessa estrutura, um novo elemento (não presente nas crônicas quinhentistas) era o sonho de Afonso Henriques.

O Juramento, sua publicização e a narrativa criada a partir dele mudaram, ao mesmo tempo em que sedimentaram, uma tradição que acumulava e somava camadas, como num palimpsesto, a partir das primeiras referências à batalha de 1139, no século XV. Num primeiro momento, chamado de "lenda épica" ou "cavaleiresca", o rei foi caracterizado como herói medieval-épico, similar ao das novelas de cavalaria ${ }^{6}$ e "composições jogralescas", pelo qual o senhor dos portugueses aparecia como personagem de traços heróicos, mas humanos, a defender os seus direitos, de sua pátria e de seus vassalos. A partir dos séculos XV e XVI, dá-se um segundo momento na criação da legenda de Afonso Henriques, a "lenda monástica" cronísticas e hagiográficas produzidas nos mosteiros, em especial, de Santa Cruz de Coimbra, onde estava o túmulo do fundador, começou-se a transformar o rei em homem piedoso e o episódio de Ourique em sinal dessa piedade, ligada à fundação de Portugal.

Foi com a Primeyra Parte da Chronica de Cister (1603), do alcobacense Bernardo de Brito, que se desenvolveu completamente pela primeira vez o caráter, ao mesmo tempo, missionário-imperial dado na eleição e de estabelecimento e manutenção do reino do Milagre, o que poderia ser considerado um terceiro - e definitivo momento na construção da legenda ${ }^{9}$. O Juramento já aparecera impresso em latim (seu suposto original) e traduzido para o vernáculo na segunda edição dos Diálogos de Vária História, de Pedro de Mariz, porém como um apêndice ao diálogo sobre o primeiro rei de Portugal ${ }^{10}$. Foi com a Chronica de Cister que apareceu incorporado à narrativa do evento, parafraseando a matéria do Juramento - e, pela própria matéria da crônica, aliando-a à trajetória da ordem cisterciense e do mosteiro de Alcobaça em Portugal.

O Juramento e as narrativas derivadas dele construíam uma estrutura especular, cumulativa e crescente de confirmação profética. De início, um estado de preocupação e reflexão sobre o evento a acontecer (o cuidado de Afonso Henriques com a batalha contra os mouros e sua apreensão com o desânimo da sua gente), que leva a um augúrio positivo (o sinal favorável dado pela leitura da vitória de Gedeão na Bíblia), que prepara um sonho misterioso (a aparição oracular de um ermitão enquanto o príncipe dormia, relaxado pelo augúrio), que anuncia uma visita de um profeta (a entrada na tenda do 
ermitão visto em sonho), que avisa sobre a aparição de Cristo, realizada em uma visão acordado (a visão da Cruz), confirmada em seu significado verbalmente na própria visão (quando Cristo faz o anúncio da vitória, da eleição do reino e da aclamação do príncipe como rei). Tudo isso comprovado e ratificado na manhã seguinte pelo levantamento como Rei pelo seu exército e pela vitória contra os cinco reis mouros no campo de Ourique. O milagre, portanto, começa na preocupação do rei com os eventos seguintes, e segue num crescendo, analogicamente ordenado, no qual cada etapa anuncia a próxima e confirma a anterior, que só se encerra na vitória contra os mouros evento fora da narrativa do Juramento, mas anunciado por Deus e confirmado na Aclamação de Afonso Henriques como Rei de Portugal pelo seu exército antes da batalha.

Esses passos perfazem, em linhas gerais, os graus de profecia definidos por São Tomás de Aquino ${ }^{11}$, que seguem o princípio bíblico - e hierárquico ${ }^{12}$ - de que quanto mais claro e menos enigmático o conteúdo profético mais certo e melhor o tipo de profecia porque mais próximo de Deus. Os dois graus mais baixos - os quais Aquino, inclusive, reluta em chamar de profecias - são, primeiro, aquele que se manifesta sob um impulso ou um instinto ao qual a pessoa obedece - no caso, a leitura da passagem bíblica -, seguido pela compreensão, por inspiração de uma luz interior, de algo, como o sinal de vitória pela analogia entre a batalha de Gedeão contra os Medianitas e o embate dos portugueses contra Ismar. Propriamente uma visão profética, por conter uma verdade sobrenatural - ou seja, por estar para além do conhecimento e compreensão possível e tangível ao humano -, figura, no degrau inicial, o sonho, a visão dormindo, na qual estão ausentes os sentidos - representado na aparição oracular do ermitão durante o sono do príncipe. Essa visão é anúncio - e, portanto, um sinal de autoridade e autorização - não só da visita do velho que tira o príncipe de seu estado de semivigília, mas da visão da Cruz quando desperto. Esta última, de Cristo crucificado, é uma visão acordada, um nível superior ao sonho profético, porque nela estão presentes os sentidos - que, pela força da verdade anunciada, são subjugados ao que se manifesta - e também as potências da alma, discernimento, vontade, memória.

Como coroamento de tudo, porém, as visões são certificadas por um nível ainda superior: o da palavra. No sonho, o ermitão fala o que irá ocorrer tranqüilizando o príncipe sonhador. Na visão da Cruz, o maior oráculo possível, Cristo, conversa diretamente com Afonso Henriques. Assegura tudo que fora anunciando antes, explica e 
clarifica seus planos e desígnios, promete um lugar especial ao rei e seu povo na cristandade e no orbe e, mais ainda, concede graciosamente ao seu eleito e vassalo todas as suas pertinentes demandas. Ao passar por diversos níveis de profecias que se autoconfirmam, a construção em várias camadas sedimenta a certeza da veracidade do milagre e conseqüentemente da sua eleição. Porém para essa construção narrativa, que amarrou (e com isso confirmou e ratificou) os diversos níveis de profecia, entre eles, o do sonho, houve um longo caminho. Caminho que pode ser observado na iconografia sobre Ourique.

A primeira imagem que localizei ${ }^{13}$ está na "Genealogia do Infante D. Fernando" (1530-1534), encomenda do infante para o iluminador flamengo Simão Bening, em cima dos desenhos de Antônio de Holanda. ${ }^{14}$ [figura 1] Na guarda esquerda, acima de uma vista da Cidade de Lisboa, estão representados os dois exércitos com suas bandeiras, no início do combate. As lanças dos mouros, de tão numerosas, acompanham todas as curvas do campo e se perdem no horizonte. Superioridade que não garante a vitória, vistos os primeiros mouros mortos pelo capitão do exército, Afonso Henriques, e deixados para trás. No centro do detalhe, acima do campo de batalha, o príncipe, vestido com sua armadura, está ajoelhado, olhando para a cruz no céu, que o ilumina com raios. Atrás dele, uma capela, a ermida na qual o Ermitão tocou o sino. A cena diurna sobrepõe dois elementos da narrativa. Um que ocorre à noite, a aparição da cruz, e, outro, pela manhã, a batalha dos dois exércitos, diferentes no tamanho e no patrocínio; um, sob a lua e a estrela de Mafoma dos seus estandartes, outro, sob a proteção da cruz das bandeiras e daquela presente no céu. A presença de Ourique na folha genealógica reforça a origem do reino e da casa real, algo constante em outras representações e documentos genealógicos e heráldicos, em especial, nos ligados às armas portuguesas. 


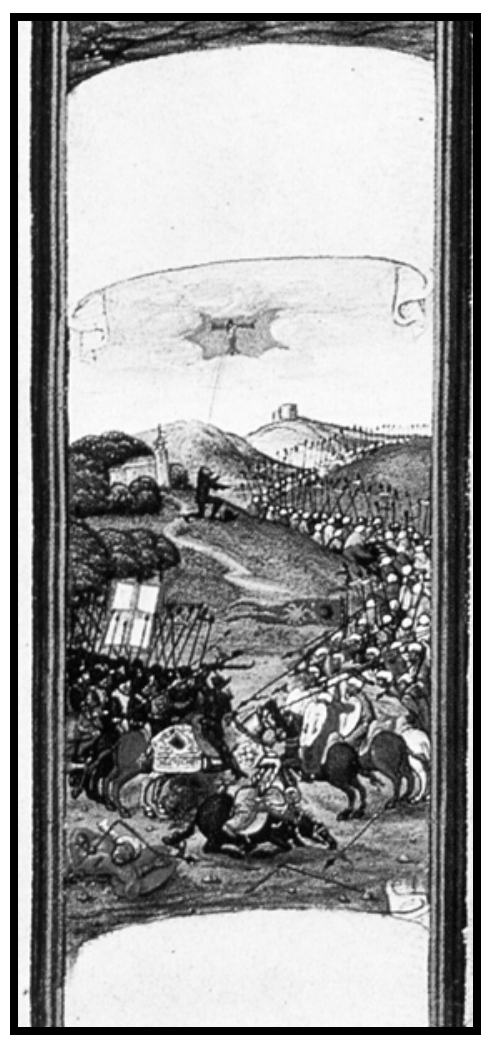

Figura 1 - Detalhe de uma folha da "Genealogia do Infante D. Fernando" (1530-1534), de autoria do ilustrador flamengo Simão Bening, representando a batalha de Ourique [fonte: Revista Oceanos, n. 26, 1986]

No "Arco dos Oficiais da Bandeira de S. Jorge", a aparição de Cristo a Afonso Henriques e a doação das chagas como armas de Portugal ocupavam espaço central e de destaque no monumento efêmero [figura 2]. Construído para a entrada de Filipe II de Portugal em Lisboa, em 1619, era um dos primeiros arcos que marcavam o caminho do rei e da corte pela capital lusa. Segundo o desenho presente na obra do cronista-mor João Batista Lavanha, que descreveu a entrada ${ }^{15}$, o arco inteiro se remetia ao Milagre e evidenciava a ligação entre o rei filipino e o fundador da monarquia lusitana. Ao gosto de um emblema, textos em latim complementavam as imagens ${ }^{16}$ - e vice-versa. 


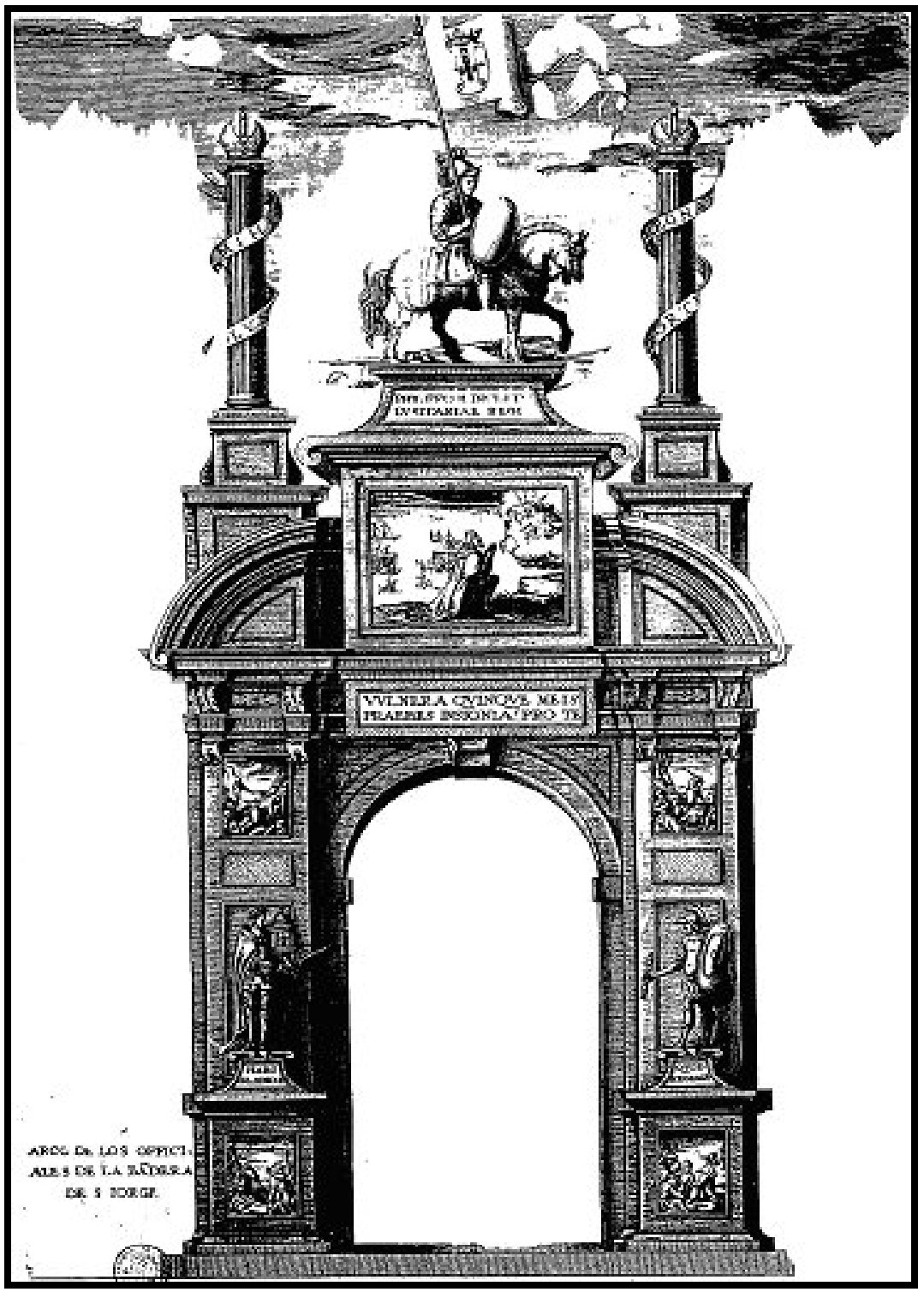

Figura 2 - Gravura do Arco dos Oficiais de São Jorge, na entrada de Filipe II em Lisboa (1619), presente no livro de Lavanha, Viagem da Catholica Real Magestade del Rei dom Filipe II ... (Lisboa, 1622). Abaixo, detalhe da aparição de Cristo a Afonso Henriques.

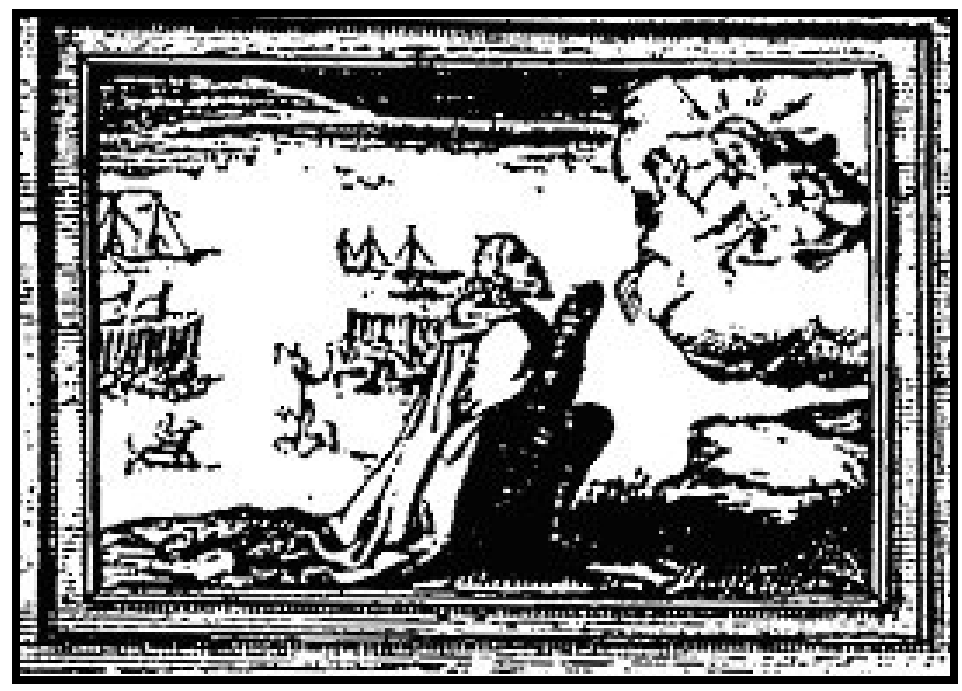


$\mathrm{Na}$ gravura do arco, no plano anterior, Afonso Henriques ajoelhado vê Cristo rodeado por nuvens, enquanto, no plano posterior, desenrola-se a batalha ${ }^{17}$. A disposição em dois planos da genealogia permaneceu, mas o destaque está na visão, que não só está no plano anterior e principal, como predomina completamente sobre a batalha. Abaixo, uma frase que explicava o milagre acentuando na doação como marca de Cristo para o reino português: "El Rei D. Afonso à Christo. Vossa cinco chagas Senhor dais por armas aos meus? Bem pertencem vossas sagradas chagas aos que por vos as hão de padecer". Sobre o desenho do Milagre, a estátua de um cavaleiro montado segurando uma bandeira com as armas de Portugal, acompanhado do texto, aos seus pés: "O reino de Portugal dedica todos os seus triunfos à [sic] Felipe II, seu inclito Rei". Como vassalos leais, os portugueses celebravam seu rei que portava as armas e bandeiras do reino marcas de Ourique e da fundação da monarquia. Independente de o rei não ser natural, mas castelhano, na disposição do arco, Filipe II era o portador legítimo das armas lusitanas dadas por Cristo a Afonso Henriques.

O arco seguinte, dos "oficiais da bandeira de S. Miguel”, reforçava e ratificava essa dimensão ao mostrar uma árvore genealógica dos reis portugueses desde Afonso Henriques até Filipe I de Portugal, emoldurada por "duas mui altas pilastras ornadas com trofeos, \& rematadas com escudo das armas Reaes de Portugal"18. A doação das armas reais ou das insígnias do poder por Cristo não era, por sinal, uma novidade na iconografia dos Filipes.

Numa gravura de 1585 [figura 3], Filipe II de Espanha e I de Portugal recebe diretamente da mão de Cristo o orbe, a coroa e a cruz ${ }^{19}$. Ao lado do rei, em segundo plano, o papa Sisto V acompanha Cristo passando as insígnias, sinal talvez da intermediação dos poderes e dos dois gládios e jurisdições do mundo: espiritual e temporal. Como Afonso Henriques, Filipe II está ajoelhado diante de Cristo, com as luvas e o elmo postos no chão e sem sua coroa. Atrás dele, paira o brasão real com as armas dos seus domínios e reinos, sustentado por cordas seguradas por um anjo. Não é possível saber se houve uma influência de Ourique, ou vice-versa, porém o que interessa é a idéia da doação das armas e sua representação iconográfica, ao que parece, construída durante o período filipino e apoiada e usada pelos Filipes. 


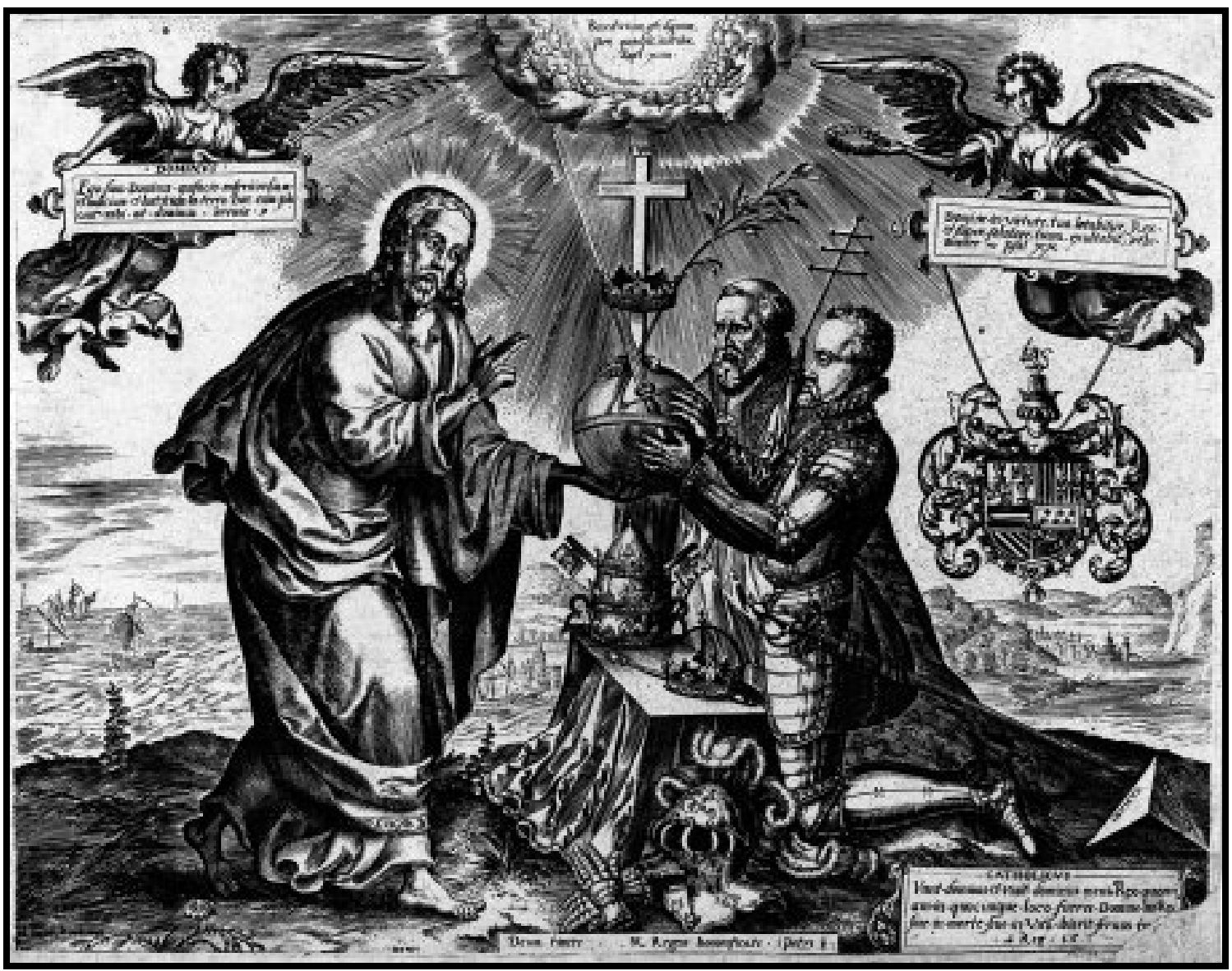

Figura 3 - Gravura de Hieronymus Wierix com Cristo investindo Filipe II de Espanha com as insígnias reais (1585). [fonte: Transactions of RHS, 12 (2002)]

O “paradigma dessa 'matriz' de Ourique como origem das armas" ${ }^{20}$ de Portugal é a gravura inserida no livro Triumpho lusitano, de 1632, impresso durante o reinado de Filipe III de Portugal e na qual se refere ao sonho com o ancião. O volume, em oitavo, é um libreto que traz impressos todos os brasões e armas das casas e postos de fidalguia do reino português, hierarquicamente dispostas do mais alto - o rei - ao mais baixo - os fidalgos. Abrindo essa série, junto a uma imagem da Nossa Senhora, está a gravura do Milagre de Ourique [figura 4]. De autoria de Agostinho Soares, é provavelmente a primeira imagem que segue a narrativa do Juramento. Se pensarmos na máxima " $u t$ pictura poesis", perceberemos que a gravura não é somente uma ilustração do Juramento (mesmo porque no Triumpho lusitano não se imprimiu o diploma), mas é a narrativa visual do que ocorre no Juramento em imagens e lugares específicos tanto do documento de Afonso Henriques quanto dos índices que definem o sonhar. Ao olhar a gravura, o espectador remeteria ao texto e veria a escrita no visual, assim como ao ouvir ou ler o texto, o leitor ou ouvinte imaginaria a gravura, e leria a gravura em palavras ${ }^{21}$. $\mathrm{O}$ argumento teológico também concorria para isso. Na explicação agostiniana sobre a 
visão, a palavra e a leitura eram entendidas a partir de uma perspectiva visual. Ao se ler a frase bíblica "Amarás ao teu próximo como a ti mesmo", operariam três classes de visões: pela primeira, se veriam com os olhos as letras escritas, pela segunda, com o espírito, se pensaria no próximo e no que seria o ausente; pela terceira, por meio do intelecto, se contemplaria o amor ${ }^{22}$. Ao traçar esse percurso imagem-escrita, o leitor do Triumpho lusitano sabe que no Milagre foram dadas as armas do reino de Portugal (desenhadas na gravura) pelo próprio Cristo e, com isso, analogicamente, estende essa doação e eleição às armas dos nobres lusitanos.

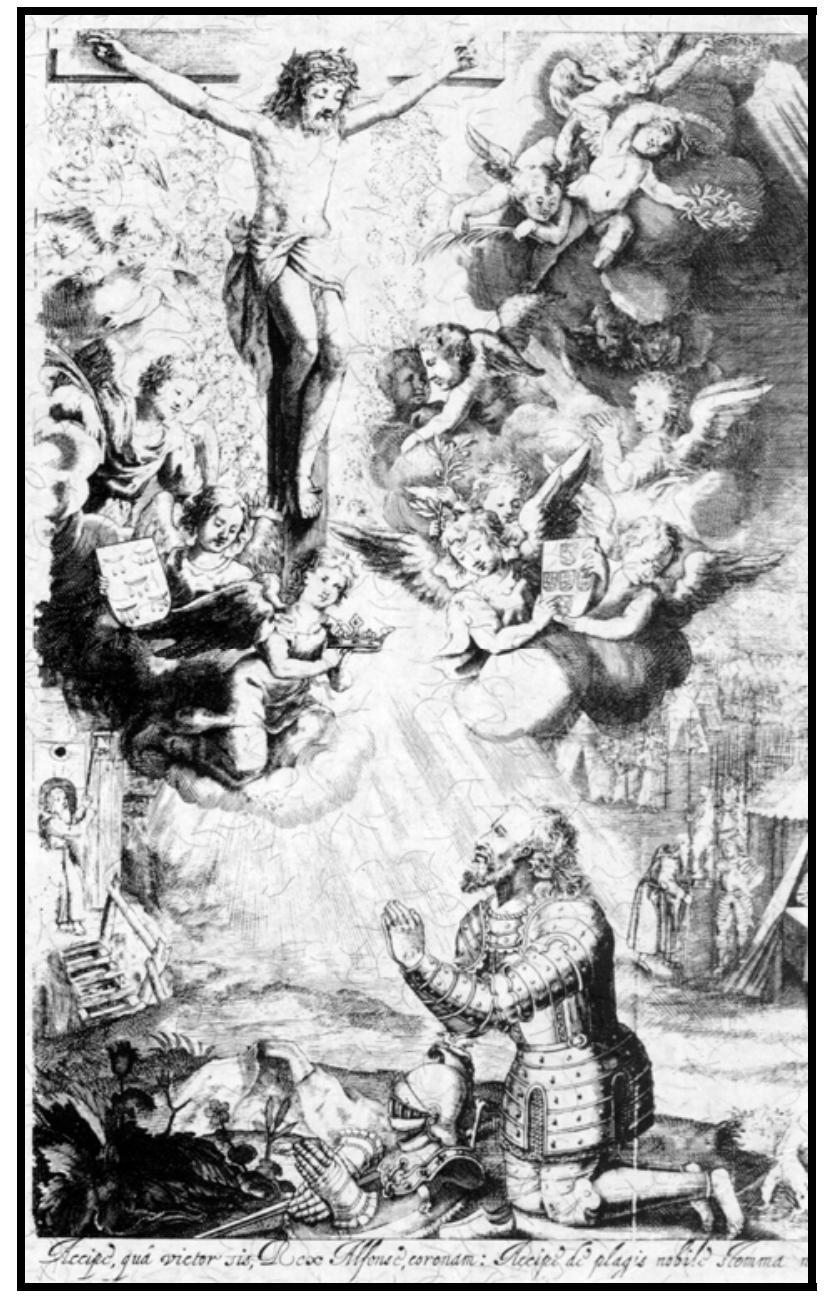

Figura 4 - Gravura do Milagre de Ourique, de Agostinho Soares, presente no livro de Antônio Soares Albergaria, Triumpho Lusitano (Lisboa, 1632). [Fonte: BN-Lisboa]

$\mathrm{Na}$ gravura de Agostinho Soares, estão presentes quase todos os elementos descritos no Juramento: Afonso Henriques ajoelhado, em posição de oração, sinal de sua piedade, descalço e sem suas armas, depositadas no chão ${ }^{23}$; Cristo crucificado no céu, à direita do príncipe, rodeado por anjos, que trazem as armas portuguesas e a coroa, como que prontos para coroar o príncipe ajoelhado, e cercado por nuvens e raios, que 
apontam para Oriente; o Ermitão na sua ermida tocando o sino; o acampamento português, e - o que interessa particularmente aqui - Afonso Henriques dormindo sobre o livro em sua tenda, com o ermitão do lado de fora. A composição da gravura, como a da folha genealógica, sobrepõe passagens do Milagre. Mas nela, como no arco, o centro é a visão de Cristo, com as armas e a coroa, ladeado pelos sinais e anúncios que a antecederam. A batalha e a vitória perderam espaço para a eleição, seguindo, por sinal, a narrativa do Juramento que se atém a esses elementos. A disposição das passagens do Juramento liga os momentos na culminação central da visão. A estrutura recortada e sobreposta não era novidade e remetia a uma iconografia, em especial, hagiográfica e bíblica, comum em Portugal e no mundo cristão. O mais importante estava em destaque, pelo tamanho maior ou pela posição central, em geral como que encerrando a narrativa. Em quadros que narravam sonhos proféticos, essa estrutura foi recorrente, nos séculos XV e XVI, para mostrar o momento da visão e as causas e efeitos do sonhado ${ }^{24}$.

Do mesmo modo, alguns elementos da composição remetiam o espectador a um vocabulário onírico. A começar pela tenda, presente no afresco de Della Francesca sobre o sonho de Constantino [figura 5] - que aqui interessa particularmente, como se verá mais adiante - , mas também em outros afrescos e iluminuras ${ }^{25}$. A tenda, em um acampamento militar, com guardas e soldados à volta, está aberta e vê-se o rei dormindo. A tenda com os panos levantados - ou, no caso de imagens civis, o quarto visto pela janela ou por aberturas - era recorrente na representação dos sonhos, um artifício que permitia ao espectador ver dentro do local onde transcorria o sonho. No caso da gravura do Triumpho Lusitano, porém, ao invés da cama, índice do sonho, o rei está sentado, adormecido e debruçado na Bíblia, que, como se sabe pela leitura do Juramento, acabara de ler.

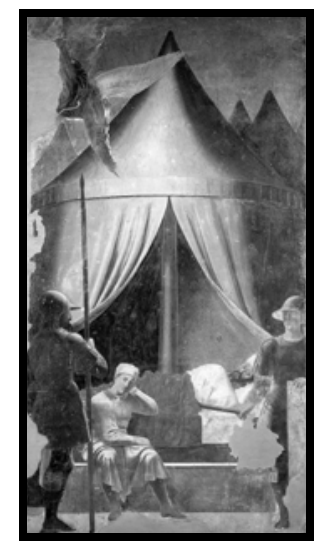

Figura 5 - Piero Della Francesca, "O sonho de Constantino" (c. 1455), parte do afresco sobre a Lenda da Santa Cruz. Capella Magiore da Igreja de São Francisco, Arezzo, Itália.

[fonte: site Web Gallery of Art] 
Além da fidelidade à narrativa do Milagre, a imagem do futuro rei dormindo sentado aparece paralela a uma mudança na iconografia do sonho, na qual, cada vez mais, os sonhadores são retratados sentados - sobretudo, à mesa. Essa mudança talvez possa ser explicada pela tentativa de representar a indistinção da fronteira entre a vigília e o sono. O sonhador sentado apareceu primeiro em alegorias do final do século XV e ao longo do XVI sobre as tentações e as virtudes ${ }^{26}$, que foram (talvez em decorrência dos sonhos alegóricos da poética medieval, tais como os "dream visions" ingleses) denominados sonhos. No século XVII, foi ligado ao lugar-comum da "vida é sonho", nome pelo qual também foi conhecido o óleo "Sonho do cavaleiro" de Antônio Pereda (c. 1650), alegoria da vanitas [figura 6]. A tópica do sonhar sentado pode ainda remeter a um estado de semivigília: "nem bem dormindo, nem de todo acordado"27, como era descrito o estado de Afonso Henriques após ler a Bíblia e deitar sobre o livro sagrado. Caracterização que seria verossímil com o estatuto de visão misteriosa - um tema recorrente na pintura seiscentista - no qual, mesmo dormindo, o bem-aventurado estaria cuidando e, por graça divina, veria mais do que com os olhos abertos ${ }^{28}$. Em substituição às frestas da tenda ou do quarto, o claro-escuro presente nos ambientes internos retratados em muitas pinturas somente aumentaria a força dessas duas matérias, tanto das sombras do sono indistintas da fugacidade da vigília quanto do paradoxo expresso no ver com os olhos fechados.

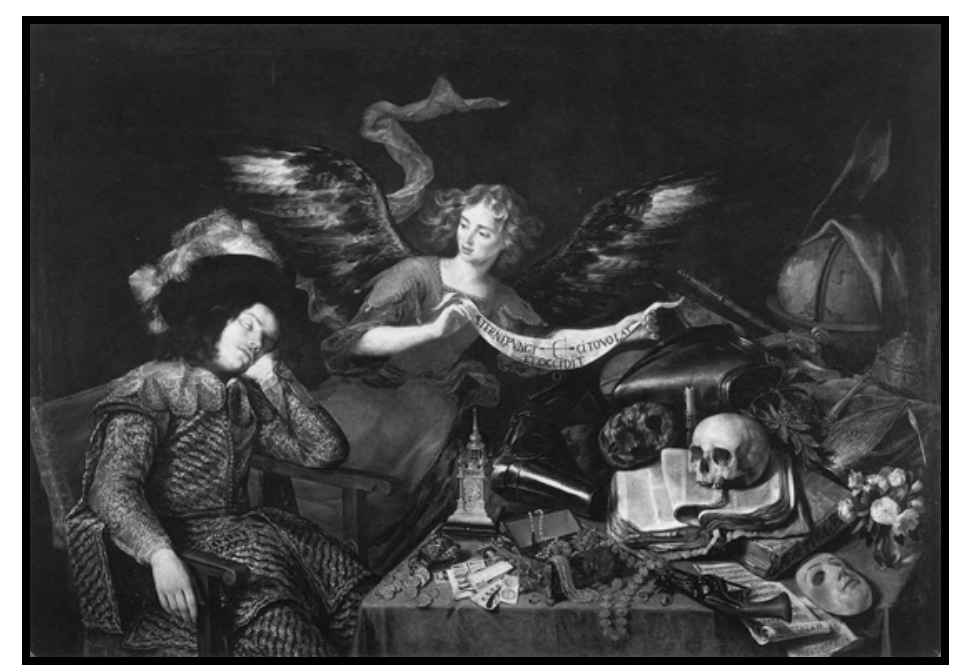

Figura 6 - Antônio Pereda "O sonho do cavaleiro" (déc. 1650), Óleo sobre madeira, Real Academia de San Fernando, Madri. [fonte: site Web Gallery of Art] 
A essa hipótese, soma-se uma comparação com a iconografia da Melancolia ${ }^{29}$. A melancolia era entendida como o humor predominante dos poetas e letrados e, numa chave neo-platônica, pensada enquanto caminho para o rapto do espírito aos céus ou aos domínios da Idéia, cujo funcionamento seria similar à visão, mas principalmente ao sonho - que seria por si só uma separação de partes do espírito do corpo físico, adormecido. Na gravura de Hans Sebald Beham, "Melencolia", de 1539 [figura 7], a alegoria da melancolia é representada por uma mulher sentada, com a cabeça apoiada na mão esquerda, segurando um compasso na mão direita que mede um orbe. Esses elementos são muito similares à famosa composição de Dürer, "Melencolia I" (1515), mas, diferentemente desta, aquela traz a mulher com os olhos fechados, como que dormindo. Há uma aproximação entre essa iconografia da melancolia e da vanitas, na qual elementos se intercambiam, e que remetem à idéia do sonho. $\mathrm{O}$ detalhe dos olhos fechados (ou semicerrados) bem como da cabeça apoiada não mão se somam à caveira típica da ars moriendi, por exemplo, no óleo de Domenico Fetti, chamado de "Melancolia" (c. 1614), mas também conhecido por "Madalena arrependida".

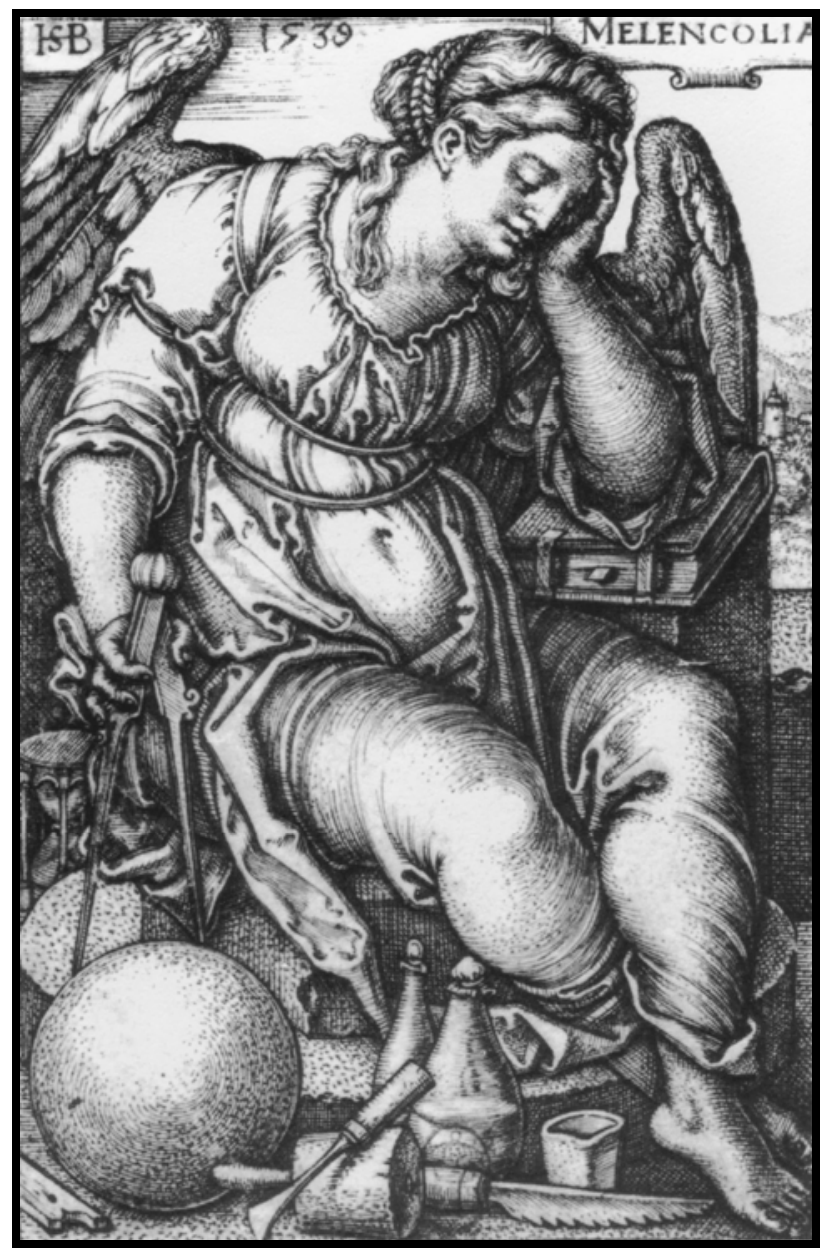

Figura 7 - Hans Sebald Beham, "Melencolia”, Gravura, 1539 [fonte: site Giornale Nuevo] 
Em cenas nas quais antes os sonhadores foram retratados deitados em camas ou em leitos foram, nos seiscentos, refeitas com eles sentados. É o caso do quadro intitulado "Sonho de São Francisco", de Bento Coelho da Silveira [figura 8], que pertence a uma série retratando a vida de São Francisco e de Santa Clara, na Igreja da Madre de Deus ${ }^{30}$.

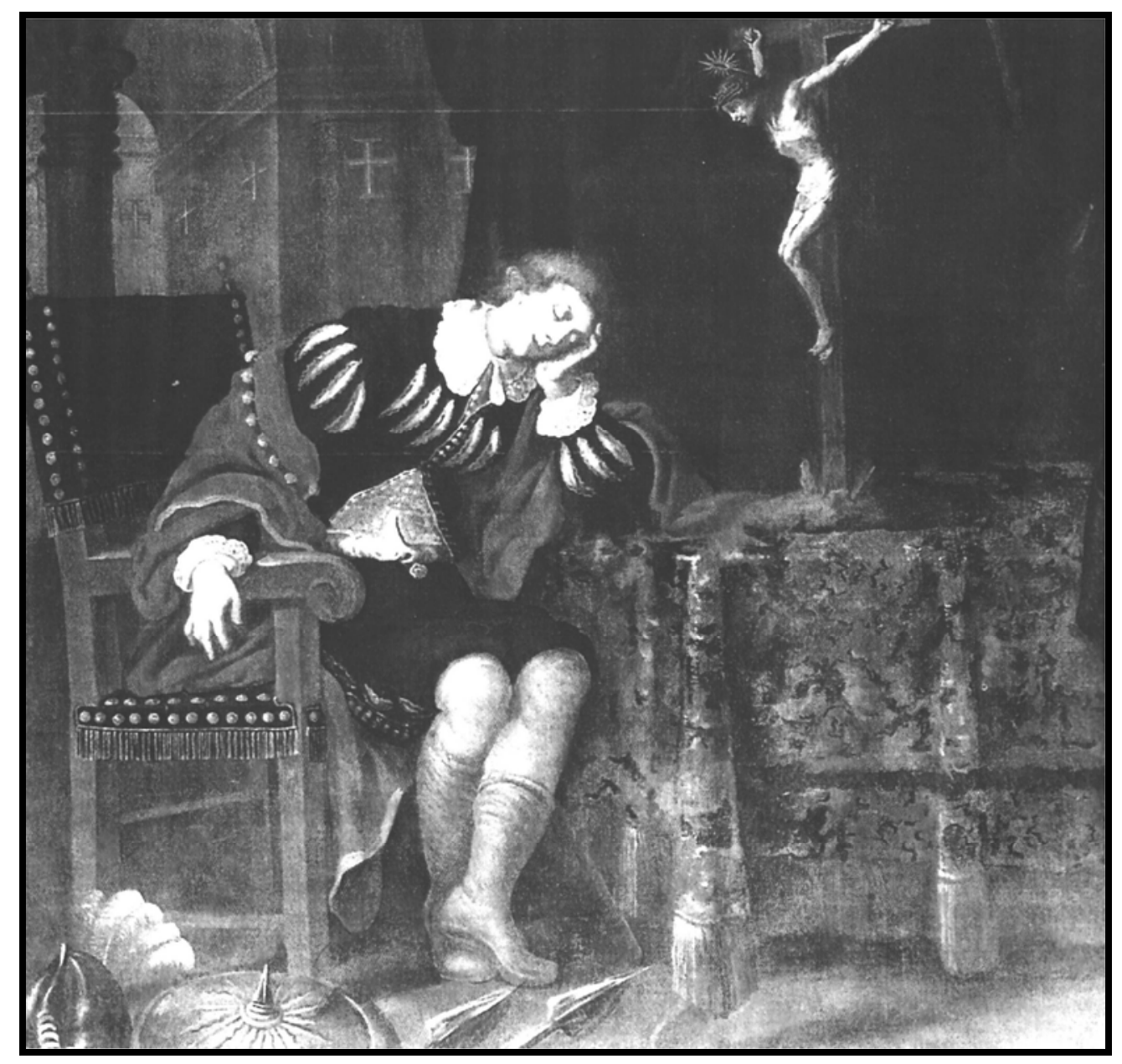

Figura 8 - Bento Coelho da Silveira, "Sonho de São Francisco" (entre 1660-1670?), óleo sobre madeira, ciclo da vida de S. Francisco e S. Clara, Igreja da Madre de Deus.

[fonte: Igreja da Madre de Deus. Lisboa, 2002]

O "sonho das armas" refere-se a uma visão do santo no qual the são apresentadas as glórias mundanas da vida militar (por meio das armas e brasões em um grande castelo) e ele, sem ter tido ainda a revelação, acredita no sonho. Na noite seguinte, a caminho do campo de batalha, novo sonho lhe aparece e lhe é revelado que as verdadeiras glórias são as vindas de Deus. No quadro de Bento Coelho, São Francisco aparece, vestido de fidalgo, dormindo sentado em um quarto, apoiando o braço na mesa, no qual está um crucifixo, suas armas estão aos seus pés; todo o cenário 
- que remete a uma igreja - emoldurado pela escuridão da noite. Uma composição muito diferente da iconografia anterior, que se centrava no castelo e nas glórias da vida militar representadas na visão - como no sonho pintado por Giotto, na série de afrescos da igreja de São Francisco em Assis (c. 1300) ${ }^{31}$. A fonte da pintura de S. Francisco de Bento Coelho provavelmente foi um buril do livro Epitome vitae et miraculorum $S$. Francisci (1631), no qual o santo aparece sentado com os olhos abertos vendo as armas e divisas ${ }^{32}$. Outras referências também podem ser levantadas, a título de hipótese. Mesmo que seja pouco provável que Bento Coelho tivesse estado na Espanha na segunda metade do século XVII, não deixa de ser curioso notar que sua composição remete ao óleo de Pereda, da década de 1650, tanto pela proximidade da disposição e dos elementos com o "Sonho do Cavaleiro" 33 [figura 6] quanto pela temática comum da vaidade das glórias mundanas. Ou ainda, e aqui interessa mais diretamente, pode-se verificar que a composição lembra a iconografia de Ourique ou da tradição que é tributária, na qual o militar se desfaz de suas armas e se entrega a Deus, representado no Cristo crucificado - como na visão de Afonso Henriques ${ }^{34}$.

Independentemente das fontes, a partir dos seiscentos, havia um repertório constante para retratar o sonho, que somava às figuras mais explícitas da cama, do leito, da tenda aberta, do quarto com janela (comuns nos desenhos medievais) outras, menos evidentes, que delineariam as tênues fronteiras entre o sono e a vigília, como o estar sentado dormindo, o ambiente interno marcado pelo claro-escuro. Entre estes, o auditório, ao se deparar com a gravura do Milagre dos Tropheos lusitanos, teria dois elementos, para além da narrativa, a fim de identificar o sonho: a tenda e o sonhador sentado.

A gravura de Agostinho Soares, de certa maneira, assumiu na representação visual de Ourique o papel que o Juramento teve na definição da narrativa textual do Milagre. Estabeleceu os elementos principais e a estrutura geral das imagens sobre o Milagre. Em 1644, na primeira impressão das Chronica del Rey Dom Ioam I de boa memoria de Fernão Lopes (em conjunto com a Tomada de Ceuta, de Zurara) ${ }^{35}$, foi estampada na folha de rosto uma gravura que reproduzia a dos Tropheos lusitanos ${ }^{36}$. [figura 9] A edição da crônica era dedicada a D. João IV e, nas licenças e no prólogo, estabelecia uma analogia entre D. João I, primeiro da dinastia de Avis, e D. João IV, primeiro de Bragança, ambos restauradores e defensores da liberdade do reino. A comparação se completava com a gravura do Milagre, fundação do reino, evento inaugural, como Avis e a Restauração - ambas figuras de Ourique. A gravura iniciava a 
narrativa textual, construída no prólogo e continuada na crônica, que mostrava haver uma ligação entre os diversos momentos fundadores do reino e das três dinastias coroadas de Portugal.

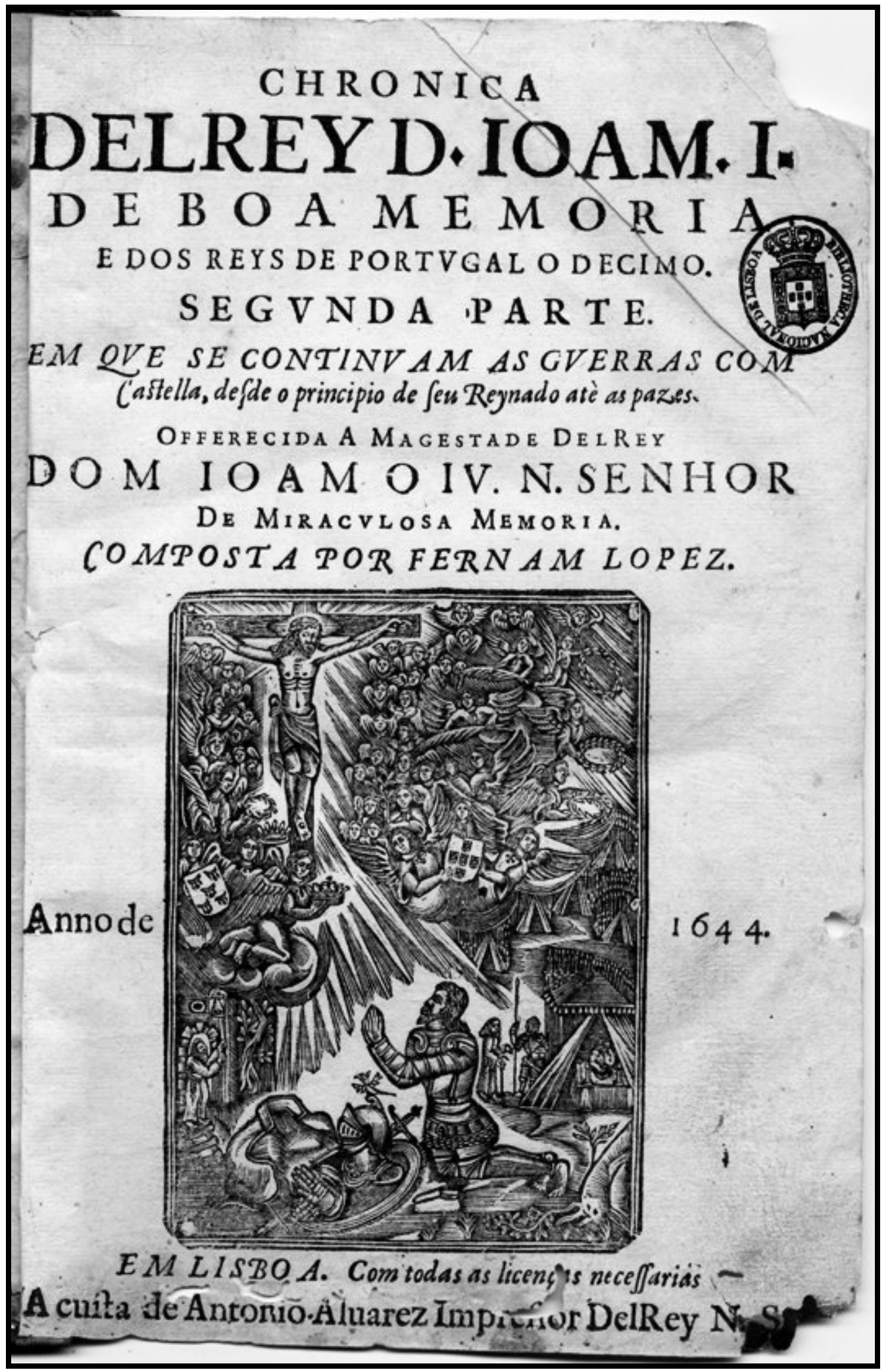

Figura 9 - Gravura do Milagre, impressa na capa da Crônica de D. João I, de Fernão Lopes, na edição de 1644. [fonte: site Biblioteca Nacional Digital] 
Essa analogia foi explicitada numa gravura do Cordel triplicado (1680), volume de sermões de D. Ardizone Spinola, na qual D. João IV está ajoelhado contemplando a visão de Cristo crucificado nos céus [figura 10]. O paralelismo se confirma pela legenda que indica que o Restaurador era a décima sexta geração profetizada em Ourique. Como tal, ao mesmo tempo em que era figurado na visão, era figura da mesma, sendo, portanto, semelhante. A similitude entre as gravuras lembrava aos leitores do Cordel da promessa de Cristo e de sua consubstanciação na pessoa do rei de Bragança, "Encuberto de Portugal [sic] nacido" como presente no título ${ }^{37}$.

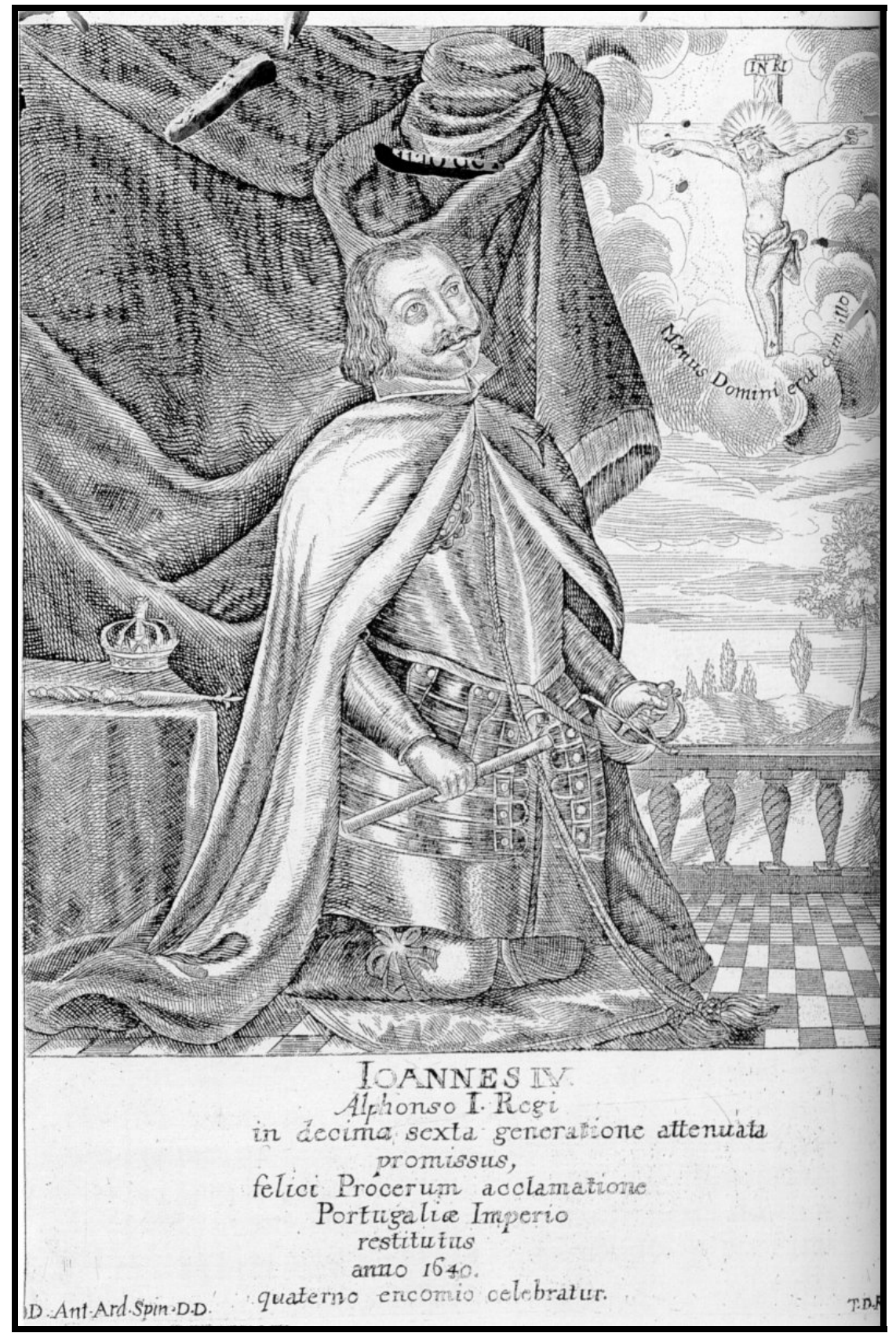

Figura 10 - D. João IV como Afonso Henriques. Gravura no livro de Antonio Ardizone Spinola, Cordel Triplicado (Lisboa, 1680). [fonte: Revista Oceanos, n. 30/31, 1997] 
A tópica do militar fiel, piamente ajoelhado, adorando uma visão santa, não é exclusividade de Ourique - a ver pela própria gravura de Filipe II. Mesmo na pintura portuguesa temos exemplos anteriores ${ }^{38}$. Essa construção, entretanto, dominou as imagens de Ourique, tornando-se tópica central - e, por que não dizer, única constante das representações. Um exemplo é a pintura feita para Colegiada de Guimarães (c. 1660) [figura 11], tomada sob proteção de D. João IV e um dos centros de produção sobre o Milagre em sua ligação com a Restauração ${ }^{39}$.

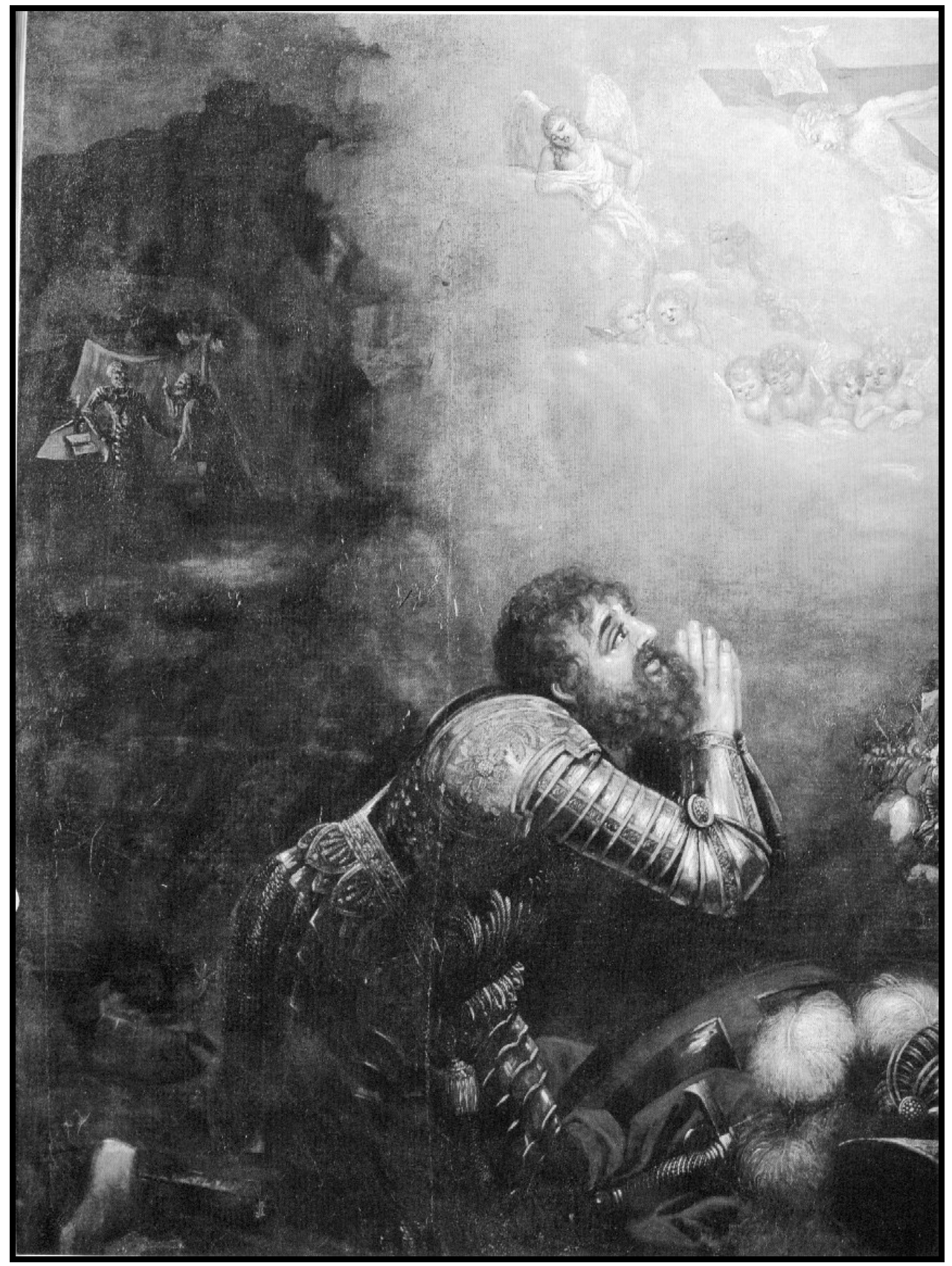

Figura 11: [Francisco da Silva ou Fr. Manuel dos Reis?] "Visão de D. Afonso Henriques na batalha de Ourique" (c. 1665), Óleo sobre painel. 173 x $152 \mathrm{~cm}$. Originalmente do Retábulo-mor da Ig. da Colegiada de N. Sra. da Oliveira, em Guimarães. Museu Alberto Sampaio, Guimarães, Portugal. [fonte: Revista Oceanos, n. 30/31, 1997] 
O óleo fazia parte de um painel maior que, segundo Vitor Serrão, era um ex-voto político pelas batalhas ganhas contra a Espanha na Restauração. O painel era composto em pares analógicos, de um lado, retratava a vitória de Aljubarrota por D. João I e a aparição da Virgem das Oliveiras, de Guimarães; de outro, Ourique e a aparição da Virgem a Afonso Henriques, antes da tomada de Lisboa. O quadro manteve a estrutura da gravura dos Tropheos: três planos que contam a história do Milagre com a visão de Cristo ao meio e em destaque. Trocou, porém, alguns elementos e inverteu a disposição do quadro, quase que como num negativo. Cristo, embora cercado pelos anjos, apareceu à esquerda de Afonso Henriques, apontando para o Ocidente. Ao invés do Ermitão tocando o sino à esquerda, mostrou a batalha no canto direito, destacando o aspecto militar - o que é verossímil em painel que exalta vitórias militares e estabelecia comparação entre Aljubarrota e Ourique. E, no lugar do futuro rei dormindo à direita, mostrou-o desperto em sua tenda conversando com o Ermitão, no lado superior esquerdo, como que indício da vigilância do rei mesmo nas trevas da noite.

Talvez, o painel represente uma mistura das duas tradições narrativas de Ourique, no qual, menos que concorrentes, se sobrepõem e combinam. A pintura de Oliveira pode ser entendida, portanto, numa tradição iconográfica própria do Milagre, que não se reporta exclusiva e diretamente às fontes textuais, inclusive, muito possivelmente, pela ignorância delas ou pelo conhecimento das narrativas por meios orais. Elementos das fontes escritas amalgamaram-se em uma nova narrativa que se reporta a elementos mais visuais. Se retomou, em parte, a temática militar da iluminura da folha genealógica, e da narrativa quinhentista, o artista reforçou no quadro certa circularidade que refletia a estrutura labiríntica e espelhada do Juramento retratada no buril de Agostinho Soares - aqui somadas a um esmaecimento das fronteiras pela escuridão que serve de fundo ao quadro. Do mesmo modo que as seguidas profecias anunciam as visões e os eventos milagrosos futuros, ao mesmo tempo em que confirmam os passados, a disposição do quadro traduz uma concepção, expressa na gravura dos Tropheos lusitanos, dos tempos - proféticos - que se sobrepõem porque participantes da Eternidade infinita, que, ao se manifestar no centro de tudo, os organiza e lhes dá sentido. A cena do ermitão anuncia a da visão da Cruz que anuncia a da vitória contra os mouros, ao mesmo tempo em que esta cena anuncia as seguintes, ou ainda, é a cena central de Cristo Crucificado que lembra (e organiza) as cenas que a antecederam e a seguirão. 
Esse espelhamento não implica um refinamento técnico ou criativo excessivo do pintor (muito menos um gênio criativo individual ou único), mas sim uma recorrência a modelos e lugares estabelecidos. Recorrência que pode ser vista nas igrejas de Castro Verde, na qual Afonso Henriques teria tido a audiência com o ermitão; ou na de Santa Cruz de Coimbra ${ }^{40}$, onde estava enterrado o rei fundador.

A figura do rei/soldado ajoelhado assume alguns outros contornos ao compararmos duas representações da visão de Constantino - uma das matrizes do Milagre de Ourique: a de Piero Della Francesca [figura 5], onde o imperador romano aparece dormindo em sua tenda, e a do Mestre da Roseira (1570?) [figura 12], na qual ele está ajoelhado, acordado. Essa diferença pode vir da multiplicidade das narrativas sobre a visão do imperador do sinal da cruz e do lema "In hoc signo vinces", cujo emblema e adoção da cruz como armas do exército teriam garantido a vitória improvável contra o tirano Maxêncio (que se pautava na mágica e na superstição) e iniciado a conversão de Roma ao Cristianismo. A narração mais difundida era a da Legenda Áurea, composta por Jacobo de Varazze no século XIII ${ }^{41}$. Na verdade, inicialmente eram duas as versões sobre a visão da cruz, apresentadas por Lactâncio e Eusébio de Cesaréia, e que aparecem combinadas e modificadas na Legenda Áurea. No capítulo 28 do primeiro livro do encômio à Vida de Constantino (c. 337) de Eusébio, Constantino estava rezando, no meio do dia, quando lhe apare a cruz e a frase "Com este sinal vencerá". No capítulo 29 , esse sinal foi reforçado, à noite, por meio de um sonho. Por essas duas visões (uma acordado e outra dormindo) ele adota o emblema da cruz para a batalha contra Maxêncio, o que lhe garante a vitória ${ }^{42}$. Na versão de Lactâncio, no capítulo 44 do Sobre a morte dos perseguidores (c. 320?) ${ }^{43}$, as instruções são dadas em sonho, mandando-o marcar os escudos com X, signo de Cristo. Na narrativa da Legenda áurea, a visão de Constantino foi contada como um dos episódios em torno do milagre da Santa Cruz e de seu achamento. O sonho, presente nas narrativas anteriores, desapareceu e foi desenvolvida a narrativa do capítulo 28 da Vida de Constantino, porém, não mais durante o dia, mas sim à noite. Um anjo acorda Constantino no meio da noite e mostra a Cruz, e o sinal que garante a vitória a Constantino contra um exército numericamente maior. No afresco de Della Francesca, Constantino está deitado, dormindo em sua tenda, e a visão pode ser em sonho - ou talvez seja um índice que reforce a idéia de a visão ter sido durante a noite. $\mathrm{Na}$ do Mestre da Roseira, o imperador vê a Cruz indicada por um anjo que o teria acordado ${ }^{44}$. Uma, baseada talvez na versão de Lactâncio, na qual Constantino vê a cruz enquanto 
dorme, porém com a presença do anjo da Legenda; outra, possivelmente, na narrativa da Legenda Áurea, na qual ele está desperto durante a noite, mas com elementos da versão de Eusébio de Cesaréia. Porém, se no afresco não há indíces da noite, exceto pelo fato de o imperador e seu pajem estarem dormindo, o óleo do Mestre da Roseira é envolto em penumbra. Mais do que isso, a cruz no céu, fora do que parece ser uma sacristia (local onde estaria Constantino rezando ao ver a Cruz durante o dia, segundo Eusébio), vence a escuridão do ambiente no qual os soldados dormem e ilumina a face do monarca ajoelhado.

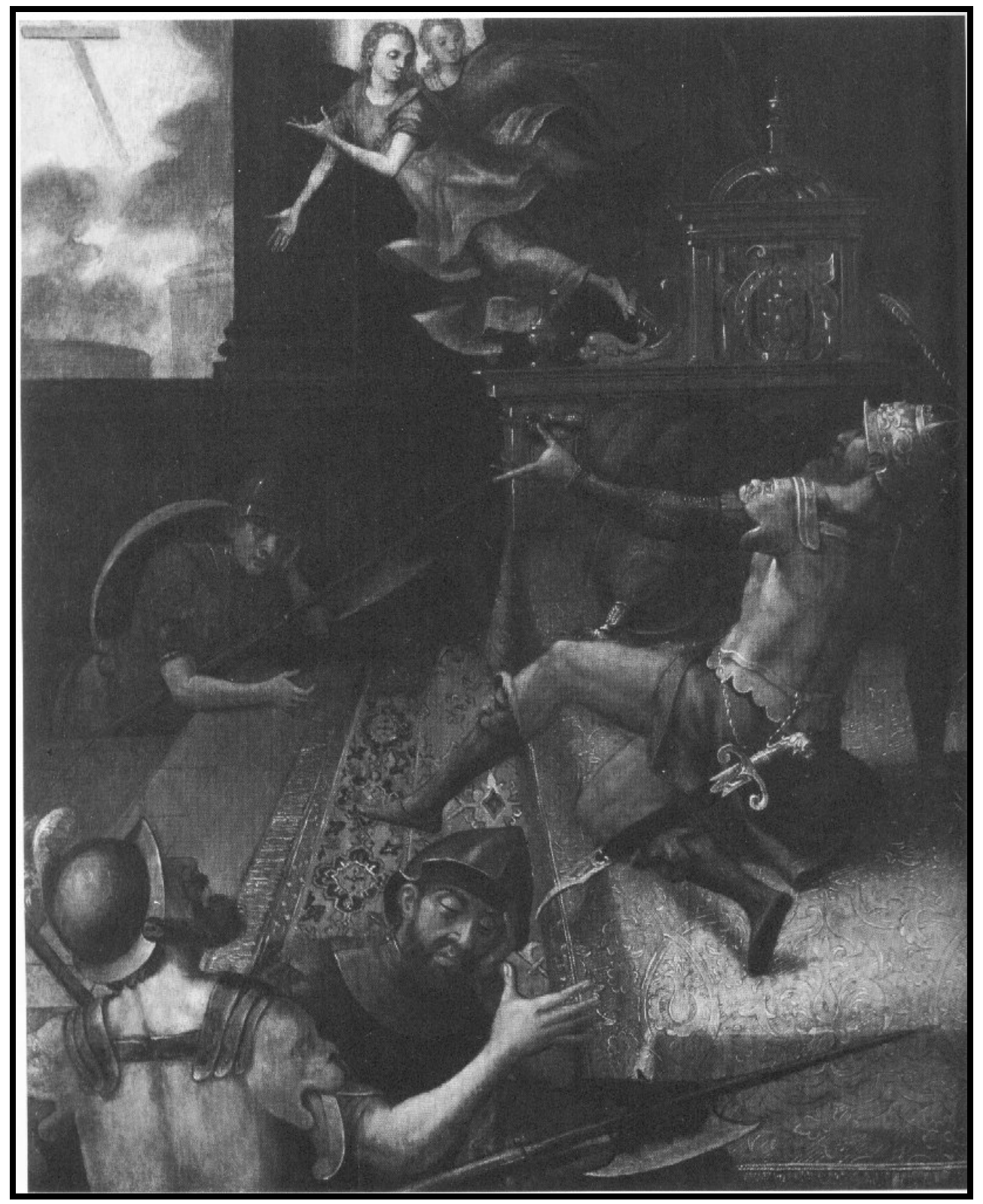

Figura 12 - Mestre da Roseira (Ambrósio Dias) "Visão [ou Sonho] de Constantino" (c. 1560), óleo sobre madeira. Procedente do antigo retábulo-mor da Ig. de Sta. Cruz de Coimbra. Seminário Patriarcal, Santarém, Portugal. [Fonte: Pintura maneirista em Portugal, Lisboa, 1995] 
Para além da hipótese de diferentes versões do milagre da Cruz, a composição do Mestre da Roseira aponta para a analogia com a figura de Afonso Henriques. Constantino é retratado com uma armadura e com barba longa, o que corresponde à descrição do primeiro rei de Portugal, e mesmo à representação do Milagre que estava na folha genealógica. Essa comparação fica reforçada se pensarmos que o quadro fazia parte do retábulo central da Igreja de Santa Cruz de Santarém, cuja correspondente em Coimbra patrocinara o pedido de canonização do monarca fundador durante o reinado de D. João III e onde estaria enterrado o monarca fundador. Se a iconografia de Afonso Henriques não estava ainda cristalizada na segunda metade do XVI, quando foi pintada a visão de Constantino do Mestre da Roseira, a relação entre o primeiro rei e o primeiro imperador cristão provavelmente já o estava - inclusive reforçando as aproximações entre as duas legendas (suposta derrota diante de um exército numericamente maior, desânimo do rei/imperador e do exército, existência de múltiplas visões e sonhos, aparição da cruz indicando uma eleição, garantia da vitória ao se assumirem o símbolo de Cristo como armas, etc. $)^{45}$.

A visão de Constantino também foi pintada, em Portugal, por Bento Coelho em inícios do século XVIII. A tela, que faz par com a "Invenção da Cruz por Santa Helena", possui, contudo, conformação diversa. Distancia-se tanto do padrão do homem deitado, dormindo em sua tenda (ou mesmo de qualquer referência ao sono) ${ }^{46}$, quanto das semelhanças com Afonso Henriques. Era similar ao padrão das gravuras feitas sobre a Legenda da Santa Cruz, gravadas pelo neerlandês Alart du Hameel, na virada do século XV para o XVI, ao que parece sob encomenda dos crúzios dos Países Baixos [figura 13]. No óleo de Bento Coelho [figura 14] (como na gravura de Hameel), Constantino está sem barba e armadura, com louros de césar na cabeça - diferente do imperador guerreiro do Mestre da Roseira, similar ao rei português. Constantino olha para o alto, vendo a Cruz; entretanto, está montado em um ginete, no campo de batalha. Uma hipótese (aduzida das leituras sobre a gravura de Hameel $^{47}$ ) para essa representação é que, ao invés de seguir a versão da Legenda Áurea ou de Lactâncio (ocorridas durante a noite, uma visão acordada, outra em sonho), tivesse sido feita a partir da Vida de Constantino de Eusébio, na qual a primeira visão é diurna, enquanto o imperador rezava. Penso, contudo, que é possível considerar outra hipótese. A narrativa imagética seria tanto daquilo que foi visto em sonho (a cruz) quanto da ação profetizada - o que, no caso português, seria reforçado com a comparação ao milagre de Ourique. 


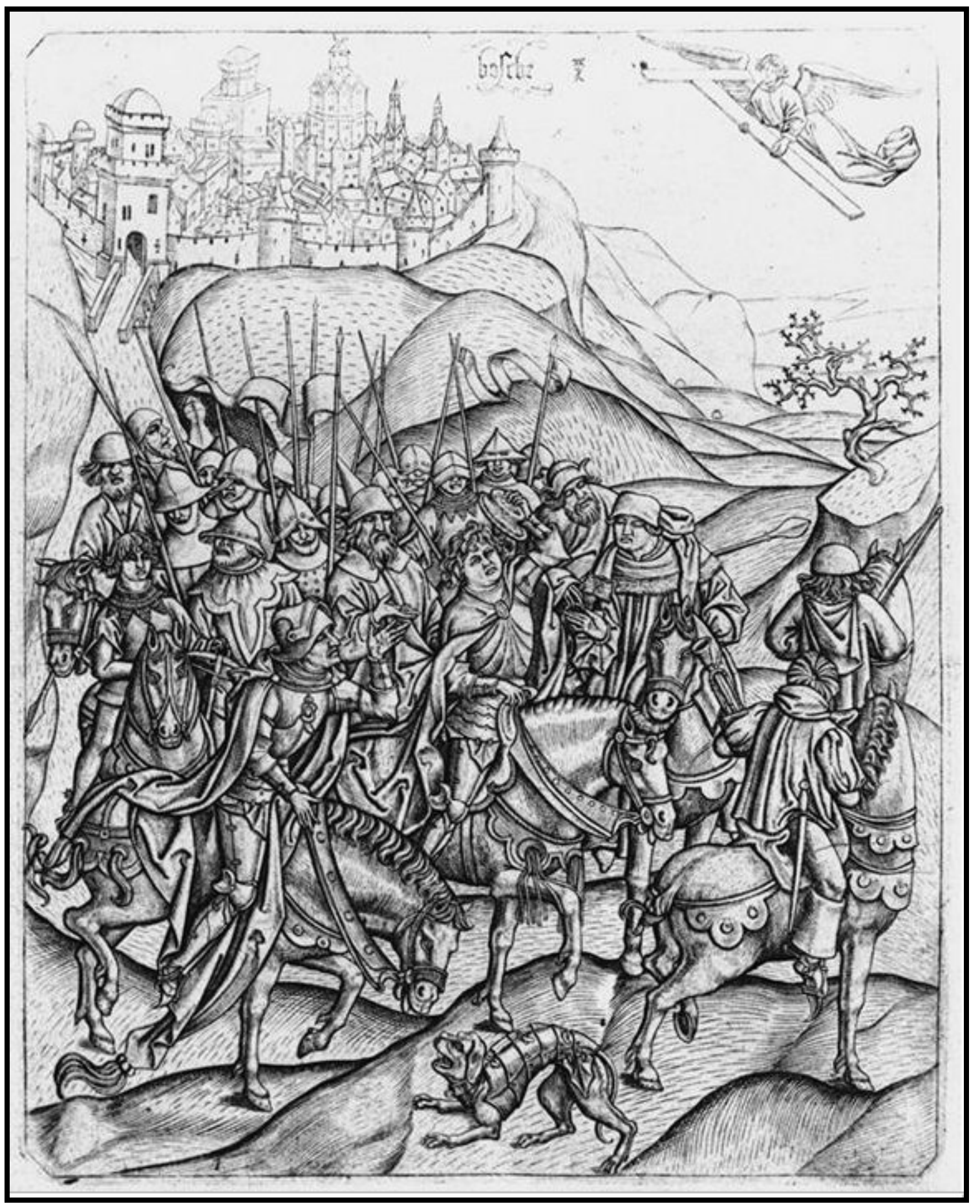

Figura 13 - Gravura de Alart du Hameel, "Visão do Imperador Constantino" [fonte: site ARTStor] 


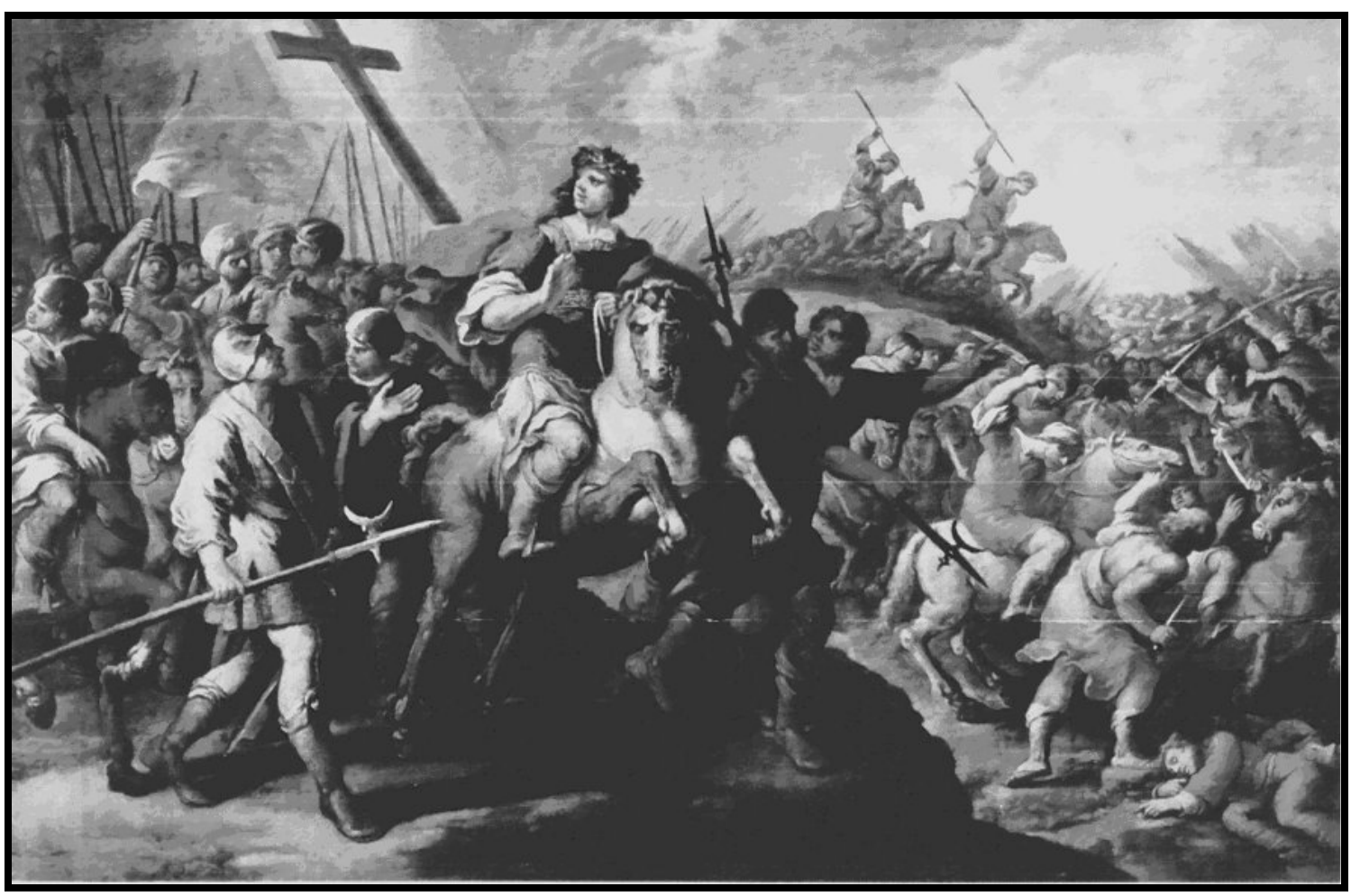

Figura 14 - Bento Coelho da Silveira, "Sonho de Constantino no Campo de Batalha" (1702?), Óleo sobre painel, Igreja Paroquial de São Pedro em Alcântara, Lisboa. [fonte: Bento Coelho e a cultura de seu tempo, Lisboa, 1998]

Se a composição não remete diretamente a Ourique, o sentido da pintura era facilmente identificado com a fundação miraculosa de Portugal, segundo Luís de Moura Sobral $^{48}$. Partilham a mesma concepção de tempo profético, com a sobreposição de planos temporais, mediados pela visão: da Cruz que anuncia a batalha vitoriosa. Se na cena predominou o embate entre os exércitos, distribuído em vários planos sucessivos, ela é instruída pela Cruz e pelo olhar de Constantino para ela. Algo reforçado pelos soldados, no primeiro plano, à esquerda, e ao lado do cavalo, que apontam para o campo de batalha ao mesmo tempo em que olham para seu imperador. $\mathrm{O}$ tempo profeticamente qualificado possibilitava ao artista sobrepor cenas de diversos momentos, pois a profecia anunciava no presente dos eleitos os futuros contingentes, e, portanto, a depender das ações humanas - imprevisíveis pelo livre-arbítrio -, fundados nos atos e escolhas passados. O sonho profético permite a enunciação de várias temporalidades. A visão da Cruz é também a visão da batalha, na economia da eternidade divina traduzida, graciosamente, por revelação e iluminação à humanidade. Nessa mesma economia, o "Sonho de Constantino" é figura de Ourique e, por metonímia, pois evento fundador, comparável e motivador de toda a história de Portugal. A visão e vitória de Constantino, em sua analogia com o feito de Afonso Henriques, inspiravam as ações lusitanas ${ }^{49}$. 
A inclusão do sonho na narrativa pelo Juramento, em finais do século XVI e reafirmada em palavra e imagem ao longo do século XVII, menos do que uma falsificação, tinha efeito verossímil de reconfirmar a profecia, tanto pela analogia interna estabelecida no espelhamento dos anúncios divinos quanto pela externa ao remeter a outros sonhos. Visualizar um sonho no Milagre era aproximar Afonso Henriques de Constantino, Ourique de Roma, o reino de Portugal do Império Romano, Ismar de Maxêncio, Mouros dos Pagãos. E vice-versa, ao ver a imagem de Constantino, também se imaginava o Juramento, causando, supostamente, efeito similar. E nessa operação analógica, além de autorizar Ourique e, portanto, a fundação de Portugal, também se permitia estender as comparações aos tempos nos quais aquelas imagens eram compostas. O espectador, ao ler as imagens e ver as palavras, atualizava seu sentido ao momento em que vivia, algo permitido pela matéria profética, que era sempre referenciada ao Eterno, o Idêntico que se repetia, de maneiras diferente, ao longo da história da humanidade. $\mathrm{Na}$ iconografia de Ourique, somada a essa função de comparação temporal, remetia-se não só à propriedade analógica da palavra profética, mas à tópica da vida é sonho e da indistinção entre aquilo que se vê e sonha, pois ambos são efeitos - também analógicos - da Verdade Criadora num mundo onde claro e escuro, vigília e sono são indistintos e se misturam em um lugar onde as coisas são feitas da mesma matéria que os sonhos.

\section{REFERÊNCIAS BIBLIOGRÁFICAS:}

AGOSTINHO, Comentário literal ao Gênesis, 1. XII, c. VI.

AUERBACH, E. Figura. São Paulo: Ática, 1997.

BOUZA, F. Palabra e imagen en la corte. Cultura oral e visual en el Siglo de Oro. Madri: Abada, 2003.

Corre manuscrito. Una historia cultural del Siglo de Oro. Madri: Marcial Pons, 2001.

BRANDÃO, A. Monarquia Lusitana, Parte terceira. (fac-símile) Lisboa, IN/CM, 1973, fl. 119 r.

BUESCU, A. I. Vínculos da Memória: o mito de Ourique. In: CENTENO, Y. K. (coord.) Portugal: mitos revisitados. Lisboa: Salamandra, 1993. 
. Um mito das origens da nacionalidade: o milagre de Ourique In: BETHENCOURT, F., CURTO, D. R. (org.) A memória da nação. Lisboa: Sá da Costa, 1991.

O Milagre de Ourique e a História de Portugal de Alexandre Herculano.

Uma Polémica Oitocentista, Lisboa: Instituto Nacional de Investigação Científica, 1987.

CANAVEIRA, M. F. Sua Majestade Fidelíssima. Da monarquia, imagem da realeza ideal e educação do rei no absolutismo português e europeu. Tese de Doutorado, Universidade Nova de Lisboa, 1997.

CLARK, S. French historians and early modern popular culture. Past and Present, 100, 1983.

. Thinking with demons. The idea of witchcraft in early modern Europe.

Oxford: Oxford University Press, 1997.

EUSÉBIO. História eclesiástica. São Paulo: Paulus, 2000, liv. 9, cap. 9.

EUSEBIUS, Life of Constantine. liv. 1, cap. 28-29, consultado no dia 30/8/2007, URL: http://www.newadvent.org/fathers/25021.htm

HANSEN, J. A., Ut Pictura Poesis e Verossimilhança na Doutrina do Conceito no Século XVII. In: MEGALE, H. (org.). Para Segismundo Spina. Língua, Filologia, Literatura. São Paulo: Iluminuras/ Edusp, 1995.

LACTÂNCIO, Sobre a morte dos perseguidores [séc. IV] (trad. José Pereira Silva), Revista Philologus, ano 1, n. 3, consultado na internet, 30/08/2007, URL: http://www.filologia.org.br/revista/artigo/1(3)19-52.html

LINDLEY CINTRA, L. F. A lenda de Afonso I, rei de Portugal (origens e evolução). Revista ICALP, v. 16-17, Junho-Setembro de 1989, p. 64-78.

LOPES, F. Chronica del Rey D. Ioam I de boa memoria e dos reys de Portugal o decimo. (...) Offerecida a magestade del Rey Dom Ioam o IV. N. Senhor de miracvulosa memoria. Composta por Fernam Lopez. Em Lisboa: A custa de Antonio Aluarez Impressor DelRey N.S., Anno de 1644, 2 v.

MARIZ, Pedro de. Diálogos de Vária história que sumariamente se referem muytas cousas antiguas de Hespana: todas as mais no taluees, que em Portugal acontecerão em suas gloriosas conquistas, antes e depois de ser leuantada dignidade Real. E outras muytas de outros reynos, dignas de memoria. Com os retratos de todos os Reys de Portugal. Avtor Pedro de Mariz. $2^{\circ}$ ed. Coimbra: Officina de Antonio de Mariz Com Priuilegio Real. MDLXXXXVIII. 
MATTOSO, José. História de Portugal. Lisboa: Editorial Estampa, 1993, t. 3, p. 62.

MEGIANI, A. P. O jovem rei encantado. São Paulo: Hucitec, 2003.

O rei ausente. Festa e cultura política nas visitas dos Filipes a Portugal

(1581 e 1619). São Paulo: Alameda, 2004.

OLIVEIRA, F. A História de Portugal (c. 1580) In: FRANCO, J.E. O mito de Portugal. Lisboa: Fundação Maria Manuela e Vasco de Albuquerque D'Orey, 2000.

PARKER, G. The place of Tudor England in the messianic vision of Philip II of Spain Transactions of the Royal Historical Society, 12, 2002, p. 174-5.

PÉCORA, A. Máquina de Gêneros. São Paulo: Edusp, 2001.

SARAIVA, A.J. A cultura em Portugal. Lisboa: Gradiva, 1992, v. 2.

SERRÃO, V. Os painéis da Colegiada de Guimarães In: $2^{\circ}$ Congresso Histórico de Guimarães : actas / do Congresso (...) sobre D. Afonso Henriques e sua época. Guimarães: Câmara Municipal de Guimarães/Universidade do Minho, 2002, v. 3.

SOBRAL, Luís de Moura. O Pintor Bento Coelho (1620-1708). Recepção Crítica e

Significado Artístico Ciberkiosk, 3 (setembro 1998), URL: http://www.ciberkiosk.pt/arquivo/ciberkiosk3/arte/bento.htm.

SOBRAL, L. M. (Comis.). Bento Coelho e a Cultura de Seu Tempo Lisboa: Ministério da Cultura/Instituto Português do Património Cultural, 1998.

Narração e simbolismo franciscano nos ciclos da Madre de Deus. In: Igreja da Madre de Deus. História, conservação e restauro. Lisboa: Ministério da Cultura, 2002.

SPINOLA, A. A. Cordel triplicado de Amor a Christo Jesu Sacramentado, ao Encuberto de Portugal nacido, a seu Reyno Restaurado, lançado em Tres Livros de Sermoens, da Felis Aclamaçam d'El Rey Dom Ioam IV emparada do Céo. Lisboa: Imp. De António Craesbeeck de Melo, 1680.

THUILLIER, J. La peinture française du XVIIe siècle et le rêve. Revue de Sciences Humaines, 211, Juillet-Septembre 1988, p. 201-2.

VARAZZE, J. Legenda Áurea (trad. e org. Hilário Franco Jr.). São Paulo: Companhia das Letras, 2003.

LIMA, Luís Filipe Silvério. Images and figures of a dreaming king: representations of Ourique's miracle and Afonso Henriques' oath in the 17TH century. História, São Paulo, v. 26, n. 2, p. 311-339, 2007.

Abstract: The article analyses the iconography of the Ourique's Miracle, based on Afonso Henrique's Oath, observing the representation of dream images in the 
17th century. It intends to trace the major topics and examples on which were based the Miracle iconography as well as the dream representation in Portugal.

Keywords: Ourique, Dream, Image

Artigo recebido em 08/2007. aprovado em 11/2007.

\section{NOTAS:}

\footnotetext{
* Este texto foi apresentado em uma versão resumida no III Simpósio Nacional de História Cultural, e é modificação de parte de meu doutorado em História defendido em 2005, na USP, sob o título Império dos sonhos: narrativas proféticas, sebastianismo e messianismo brigantino, que contou com o apoio da Fapesp.

** Professor de História Moderna, Departamento de História, Campus Guarulhos, Universidade Federal de São Paulo (Unifesp), CEP 07252-312, Guarulhos - SP, Brasil; Pesquisador da Cátedra Jaime Cortesão, FFLCH, Universidade de São Paulo (USP), CEP 05508-900, São Paulo - SP, Brasil.

${ }^{1}$ Para o conceito de gramática de Wittgenstein nos estudos históricos e das letras, ver: Clark, 1983; cf. Clark,. 1997; cf. Pécora, 2001.

${ }^{2}$ Hansen,in: Megale, 1995, p. 201-14.

${ }^{3}$ Bouza, 2003; cf. Bouza, 2001.

${ }^{4}$ Auerbach, 1997.

${ }^{5}$ Lindley Cintra, 1989, p. 64-78; Saraiva, 1992, v. 2, p. 120ss.

${ }^{6}$ MEGIANI, 2003.

${ }^{7}$ Em diversas passagens nas crônicas mais antigas, Saraiva identificou resquícios de versos, sinais, junto às diversas variantes existentes, da marca oral, jogralesca das primeiras composições da lenda cavaleiresca. O interessante é que, na Quarta Crônica Breve de Santa Cruz, a menção à batalha de Ourique, com a adoção das quinas e Afonso Henriques sendo chamado de rei, teriam sido um recurso de ligação, em prosa, entre dois poemas distintos. Saraiva, 1992, p. 132-63.

${ }^{8}$ Lindley Cintra,1989; Saraiva, 1992.

${ }^{9}$ Haveria um outro momento derradeiro que seria da desconstrução do mito e da acusação de o Juramento ser forjado e o Milagre, inventado. Algo que teria começado de modo mais sistemático na segunda metade do século XVIII, mas que ganhou projeção e entrou para o debate em Portugal, a partir das críticas de Alexandre Herculano e da polêmica que se seguiu. Para esse aspecto e mesmo para uma visão geral da construção do mito desde os séculos XIV-XV, ver: Buescu, 1987.

${ }_{10}^{10}$ Mariz, MDLXXXXVIII.

${ }^{11}$ Suma Teológica, II-II, q. 174, a. 3

${ }^{12} \mathrm{cf}$. Agostinho, Comentário literal ao Gênesis, 1. XII, c. VIIss.

${ }^{13}$ Agradeço aqui a Ana Paula Megiani, que indicou a imagem. Ela também está reproduzida em seu livro O jovem rei encantado (São Paulo: Hucitec, 2003).

${ }^{14}$ Oceanos, n. 26, 1996, cf. MATTOSO História de Portugal, t. 3, p. 62.

${ }^{15}$ LAVANHA, J. B. Viage de la Catholica Real Magestade del Rei D. Filipe III N.S. al Reino de Portugal I Relaacion del Solene Recebimiento que en el se hizo su Magestad. Madri: Por Thomas Iunti Impressor del Rei N.S., 1622. Para as entradas régias e Lavanha, ver: Megiani, 2004. Agradeço à Ana Paula Megiani pelo empréstimo da cópia do volume de Lavanha.

${ }_{17}^{16}$ Megiani, 2004, p. 207-208.

${ }^{17}$ Cf. CANAVEIRA, 1997, cf. cap. 3.

${ }^{18}$ LAVANHA, J. P. op. cit., p. 27.

${ }^{19}$ cf. Parker, 2002, p. 174-5.

${ }^{20}$ Buescu, in: Centeno, 1993; cf. Buescu, in: Bethencourt, Curto (org.),1991; Buescu, 1987.

${ }^{21}$ Bouza, 2003.

${ }^{22}$ AGOSTINHO, Comentário literal ao Gênesis, 1. XII, c. VI.
} 
${ }^{23}$ No Juramento, ele tira suas roupas, contudo. Pode-se supor que não seria pio e cristão estar pelado diante de Cristo e de anjos após as determinações de Trento e de Roma acerca do corpo nu.

${ }^{24}$ Alguns exemplos, entre muitos: Henrique Francisco (act. 1508, f.1518), "Nossa senhora das Neves", escola Luso-Flamenca, painel a óleo, Museu Nacional de Arte Antiga, Portugal; Benozzo Gozolli "Cenas da vida de S. Francisco" (1450-1452), afresco, Capela de São Francisco de Montefalco, Itália; Rogier Van Der Weyden "Sonho do papa Sergius" (1440), óleo sobre papel, National Gallery London; Gillaume Fillastre. "Allégorie de Magnanimité" iluminura em "Toison D'Or", (séc. XV-XVI), BNF, Fond Richelieu, Manuscrits Occidenteaux, Français, f. 138.

${ }^{25}$ Cf. Agnolo Gaddi, "Sonho de Constantino" (séc. XIV), do ciclo de afrescos a Santa Cruz, Igreja de Santa Cruz, Florença, Itália; "Sonho de Artur", iluminura no manuscrito "Mort de le roi Artur" (séc XV), F. 294V, BNF, Fundo Manuscrits Occidenteuax Français.

${ }^{26}$ Cf. Albrecht Dürer "A tentação de Idler ou o Sonho do Doutor" (c. 1498), Gravura, Metropolitan Museum of Art, Nova York.

${ }^{27}$ Brandão, 1973, fl. 119r.

28 "Sonho das Armas", buril do livro Epitome vitae et miraculorum S. Francisci (1631), Apud: Igreja da Madre de Deus. História, conservação e restauro. Lisboa: Ministério da Cultura, 2002; cf. VIEIRA, A. Sermão do Esposo da May de Deus S. Ioseph No dia dos Annos de Rey Nosso Senhor Dom Ioam IV Que Deus guarde por muytos, \& felicíssimos. Prègou o na Capella Real o P. Antonio Vieira da Companhia de IESV Prègador de S. Magestade Lisboa, Domingues Lopes Rosa, 1644; VIEIRA, A. Xavier dormindo, e Xavier acordado (...) Oitava parte. Lisboa, Miguel Deslandes, 1694.

${ }^{29}$ Sobre a Melancolia, vali-me imenso dos estudos de Sérgio Alcides, que desenvolve uma pesquisa sobre as relações entre poética, melancolia e razão de Estado, tendo como objeto a atuação e a obra de Sá de Miranda.

${ }^{30}$ Outro é o sonho do patrício com N. Sra. das Neves, no qual o patrício aparece deitado, numa representação da escola luso-flamenga do início do séc. XVI que está no Museu de Arte Antiga, e depois sentado, no painel de Murilo para igreja de Santa Maria, a Branca, em meados do XVII.

${ }^{31} \mathrm{Na}$ série há mais dois sonhos, nos quais os sonhadores estão dormindo deitados: o "sonho de Inocêncio III" e o "sonho de S. Gregório". Um século e meio mais tarde, similar composição apareceu no ciclo de afrescos com cenas da vida de S. Francisco, pintado por Benozzo Gozzoli no monastério franciscano em Montefalco (1450-1452), com a visão de S. Francisco da Igreja Triunfante (sonho que se segue ao sonho das armas), na segunda cena, e o sonho de Inocêncio III, na quinta cena.

${ }^{32}$ Sobral, 2002.

${ }^{33}$ Há uma tradição que afirma que Bento Coelho fez um estágio na Espanha, o que, segundo Luis de Moura Sobral, é verossímil (embora não que tenha sido discípulo de Rubens, como diz a mesma tradição). Porém se o fez, viajou provavelmente para Espanha possivelmente antes de 1650, por volta de quando o quadro de Pereda foi executado. SOBRAL, L. M. O Pintor Bento Coelho (1620-1708). Recepção Crítica e Significado Artístico Ciberkiosk, 3 (setembro 1998), URL: http://www.ciberkiosk.pt/arquivo/ciberkiosk3/arte/bento.htm.

${ }^{34}$ A ligação com Ourique e os episódios de visão da Cruz se reforçam pois Bento Coelho pintou o tema no "Sonho de Constantino".

${ }^{35}$ Lopes, 1644, 2 v.

${ }^{36}$ Uma gravura similar foi reproduzida no início do séc. XIX, significativamente, no frontispício de um texto miguelista: D. Miguel I obra a mais completa e concludente que tem apparecido na Europa sobre a legitimidade e inanferiueis direitos do Senhor D. Miguel I. Lisboa, 1829.

${ }^{37}$ Spinola, 1680.

${ }^{38}$ Por exemplo, o quadro retratando um cavaleiro da ordem de Santiago adorando a Virgem, no Museu de Arte Antiga. Mestre anônimo, "Aparição da Virgem a um Mestre da Ordem de Santiago" (c. 1520-1530), Óleo sobre Tela, Museu Nacional de Arte Antiga, Lisboa.

${ }^{39}$ Serrão, 2002, v. 3.

${ }^{40}$ Cf. Brito, 1949. v. V,

${ }^{41}$ Varazze, 2003.

42 EUSEBIUS, Life of Constantine. liv. 1, cap. 28-29, consultado no dia 30/8/2007, URL: http://www.newadvent.org/fathers/25021.htm.

${ }^{43}$ LACTÂNCIO, Sobre a morte dos perseguidores [séc. IV] (trad. José Pereira Silva), Revista Philologus, ano 1, n. 3, consultado na internet, 30/08/2007, URL: http://www.filologia.org.br/revista/artigo/1(3)1952.html

${ }^{44}$ Vitor Serrão nomeia a pintura como "O sonho de Constantino" e a considera como a única representação portuguesa do episódio, contudo, a partir da comparação com a narrativa proposta pela Legenda percebe-se que não um sonho, mas sim uma visão acordado e, se considerarmos a imagem de 
Bento Coelho da Silveira como um exemplar da legenda da Santa Cruz, podemos pensar em duas representações (Serrão, 1995, p. 207).

${ }^{45}$ Fernando de Oliveira, por volta da década de 1580, inclusive comparou a visão e vitória de Afonso Henriques com a versão de Eusébio de Cesaréia, porém da sua História eclesiástica, que menciona a batalha sem muitos detalhes: Oliveira, in: Franco, 2000, p. 444, cf. Eusébio, 2000, liv. 9, cap. 9.

46 Jacques Thuillier, em artigo na Revue de Sciences Humaines, ressaltou que não é o sonho que é representado na pintura francesa seiscentista (segundo ele, o ambiente onírico era contrário à pintura), mas sim o sonhador. $\mathrm{O}$ comentário pode ser estendido aos quadros analisados, com exceção deste, no qual o que aparece é a matéria do sonho e não o sonhador. Thuillier, 1988, p. 201-202.

47 The Illustrated Bartsch. Vol. 9, pt. 2, commentary, Early German Artists (consultado por meio da base ARTstor. www.artstor.org).

${ }^{48}$ Sobral (Comis.)., 1998.

49 Por exemplo, na sua entrada na guerra de Sucessão de Espanha, época na qual provavelmente a tela foi encomendada a Bento Coelho. Bento Coelho e a Cultura de Seu Tempo, 1988. 